\title{
Personal Protective Equipment (PPE) use among emergency eye care professionals in the UK during the COVID19 pandemic
}

\author{
Amy-lee Shirodkar ${ }^{1} \cdot$ lan De Silva ${ }^{2} \cdot$ Seema Verma ${ }^{1,3} \cdot$ Sarah Anderson $^{4} \cdot$ Polly Dickerson $^{4} \cdot$ Francine Walsh $^{5}$. \\ Dilani Siriwardena ${ }^{1} \cdot$ Felipe Dhawahir-Scala ${ }^{6}$
}

Received: 24 April 2020 / Revised: 7 May 2020 / Accepted: 7 May 2020 / Published online: 21 May 2020

(c) The Author(s), under exclusive licence to The Royal College of Ophthalmologists 2020

\begin{abstract}
EEC staff were provided with rapidly changing personal PPE guidance by Public Health England (PHE) with specific subspecialty advice from the British Emergency Eye Care Society (BEECS) and the Royal College of Ophthalmologists (RCOphth) UK during the COVID19 pandemic. BEECS undertook a baseline survey of its members after the initial response from the RCOphth 16/3/20 mirroring Public Health England (PHE) advice and a follow- up survey after the guidance was updated on 9/4/20. A combined total of 84 responses were received. Improvements after RCOphth changes between the two surveys from hospital respondents showed increases in temperature screening (13\%), scrub use (34\%), use of aprons (31\%), masks (4\%), eye protection (35\%), gloves (25\%) and slit lamp guard (1\%). Our findings demonstrate a positive and significant adaptation of PPE in response to change in guidance published by PHE, RCOphth and BEECS between 16/3/20 and 11/4/20. The COVID19 pandemic has rapidly taken over the normal activity of Ophthalmic departments creating unprecedented challenges. Following initial confusion and vulnerability expressed by EEC professionals to PPE guidance, most Trusts appear to have adapted and are doing similar things. The response has been swift and effective as a result of good team work and early advice from BEECS and the RCOphth. On the whole, management teams are listening.
\end{abstract}

\section{Introduction}

The novel coronavirus disease 2019 (COVID19) caused by severe acute respiratory syndrome coronavirus-2 (SARS-CoV-2) was declared a global pandemic by the World Health Organisation on the 11th of March 2020 [1]. The Royal College of Ophthalmologists response for UK ophthalmic departments was to reduce activity and provide hospital services for sight-threatening emergencies

$\triangle$ Felipe Dhawahir-Scala

felipe.dhawahir@btinternet.com

1 Moorfields Eye Hospital, London, United Kingdom

2 Leicester Royal infirmary, Leicester, United Kingdom

3 St Thomas' hospital, London, United Kingdom

4 York Teaching Hospitals NHS Foundation Trust, Scarborough, United Kingdom

5 Royal Bolton Hospital, Bolton, United Kingdom

6 Manchester Royal Eye Hospital, Manchester Foundation Trust, Manchester, United Kingdom due to the threat of fatal COVID19 complications among the UK population [2]. The college of optometry, similarly, provided guidance for practices to stop routine GOS services and only provide emergency eye services by accredited MECS/MECS type practices [3].

Emerging publications from China, where the disease was first reported, highlighted the increased risk of transmission of SARS-CoV-2 for health care workers working in close contact with infected patients [4]. Reports found SARS-CoV-2 present on ocular surfaces and a cause of conjunctivitis of varying incidence [5-7]. Emergency eye care (EEC) professionals come into close contact with patient's ocular surfaces while managing ocular emergencies in both community and hospital settings, increasing their risk of acquiring COVID19 [5-7]. Personal protective equipment (PPE) are (is) used to reduce the risk of health care workers exposure to potentially infectious droplets while managing a patient infected with SARS-CoV-2 [8].

EEC staff were provided with rapidly changing personal PPE guidance by Public Health England (PHE) with specific subspecialty advice from the British Emergency Eye Care Society (BEECS) and the Royal College of Ophthalmologists (RCOphth) UK. 
Table 1 COVID19 Time line of events + RCOphth PPE guidance [1, 2].

12/2019 Cluster of pneumonia of unknown aetiology - Wuhan, China

7/1/20 New virus identified

11/3/20 WHO global alert COVID19 pandemic Summary of PPE guidance*

16/3/20 RCOphth—Coronavirus RCOphth update-need to know points

27/3/20 RCOphth PPE guidance

$9 / 4 / 20$ RCOphth PPE guidance
Hand hygiene, good tissue practice, slit lamp cleaning and SLG

As above plus:

Asymptomatic patients-SFM

Asymptomatic and AGP-SFM, disposable gloves,

FRG, eye protection if risk of splash/droplet

COVID19 suspect or confirmed-Isolate, SFM, gloves, apron, eye protection if risk of splash/droplet

As above plus:

AGP-FFPR, eye/face protection

ITU/HDU

All eye patients-Gloves, FRA, FFSM11R, face/eye

protection

Advice on scrubs
Survey 1

Carried out between 4-6/4/20

covers this PPE advice

Survey 2

Carried out between 11-20/4/20

covers this change in advice

SFM surgical face mask, $A G P$ aerosol generating procedures, $F R G$ fluids resistant gown, $F F P R$ filtering face piece respirator, $F R A$ fluid resistant apron, FFSM11R fluid resistant type $11 \mathrm{R}$ surgical mask, SLG slit lamp guard.

*Abbreviated summary of advice from online published guidelines [2].

Table 2 Survey 1 and 2 questions.

Survey $1 \quad$ Survey 2

Do all your patients have their temperature checked on arrival to hospital/eye department?

Do you wear scrubs when seeing both low (asymptomatic/no contacts) and high-risk COVID19 patients in your Ophthalmology department?

What type of PPE do you wear while examining low risk, asymptomatic patients?

My hospital provided me with adequate information regarding PPE My hospital is providing me with adequate information regarding PPE

The management responsible for the provision of PPE in my

department listen to my view and take it into account

The management responsible for the provision of PPE in my department/ practice listens to my view and takes it into account

I have experienced a shortage of PPE during an emergency eye care session

In the last week I have experienced a shortage of PPE during an emergency eye care session

I have experienced objection or threat of disciplinary action to wearing PPE I have provided myself

In the last week I have experienced objection or threat of disciplinary action to wearing PPE I have provided myself

The management responsible for the provision of PPE in my department have changed its guidance to me in the last 2 weeks

The management responsible for the provision of PPE in my department/ practice have changed its guidance to me in the last week (since the last survey).

\section{Aim of study}

The aim of this study was to survey EEC professionals in primary and secondary care about (and evaluate) the provision and response of departments to information given with regard to PPE during the COVID19 pandemic period.

\section{Methods}

BEECS undertook a baseline survey of its members after the initial response from the RCOphth 16/3/20 mirroring Public Health England (PHE) advice and a follow-up survey after the guidance was updated on 9/4/20. See Table 1 for time line of events and RCOphth PPE guidance and Table 2 for survey questions.

Each survey was completed by BEECS members delivering EEC services in both primary and secondary care during the COVID19 pandemic. A total of 50 responses were received for the baseline survey and 34 for the followup survey.

\section{Results}

A combined total of 84 responses were received for the surveys sent. 

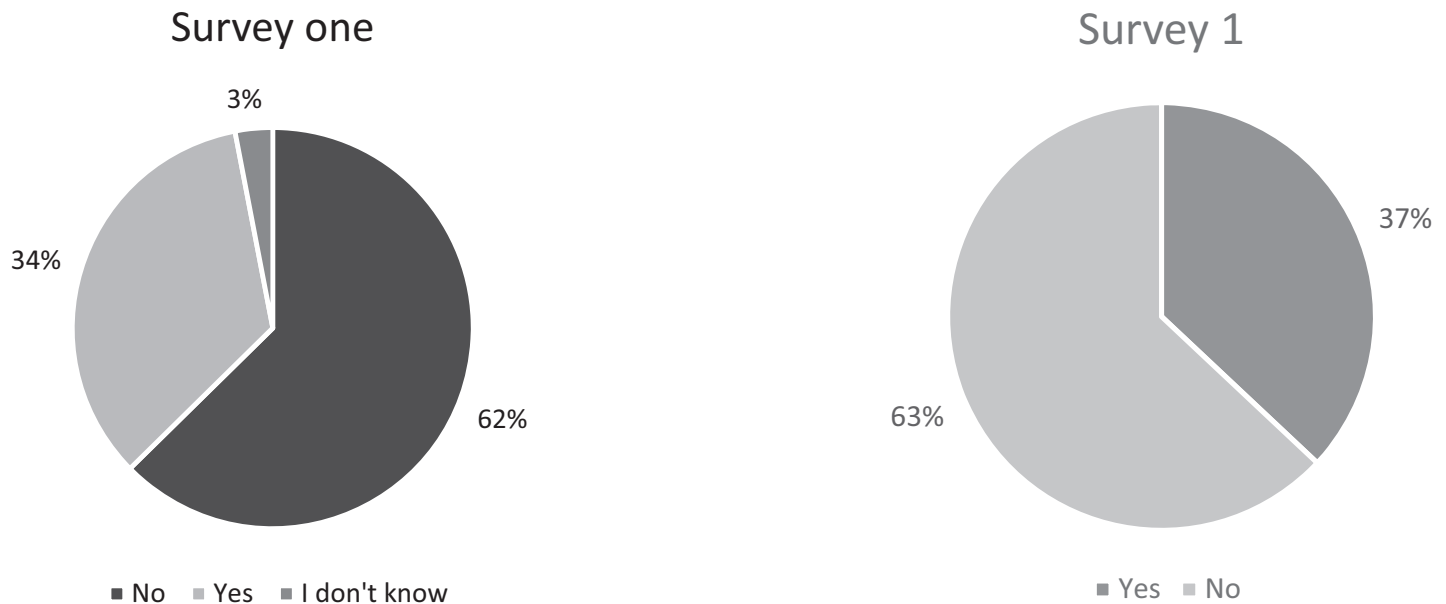

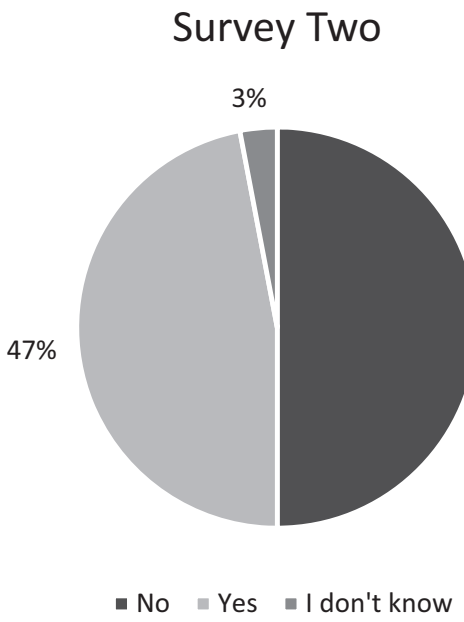

Fig. 1 Survey question: Do all your patients have their temperature checked on arrival to the hospital/eye department?

\section{Hospital respondents}

Hospital respondents totalled 29 for survey 1 (20\% stand alone eye unit, 52\% University Hospital/Acute Trust and $27 \%$ District General Hospital) and 32 for survey 2 (19\% stand alone eye unit, 44\% University Hospital/Acute Trust and 34\% District General Hospital).

Figures 1, 2 demonstrate a change between the surveys for temperature screening with an increase of $13 \%$ noted and an increase of $34 \%$ in the use of scrubs to examine lowand high-risk COVID19 patients. Other changes noted was an increase in the use of aprons (31\%), masks (4\%), eye protection $(35 \%)$, gloves $(25 \%)$ and slit lamp guard $(1 \%)$ (Table 3).

Hospital management were seen to be more receptive to the demands of EEC professionals after the 9/4/20 RCOphth guidelines were updated, an increase of $21 \%$ and $40 \%$ more were providing PPE advice. An improvement in the supply of PPE and relaxation on EEC

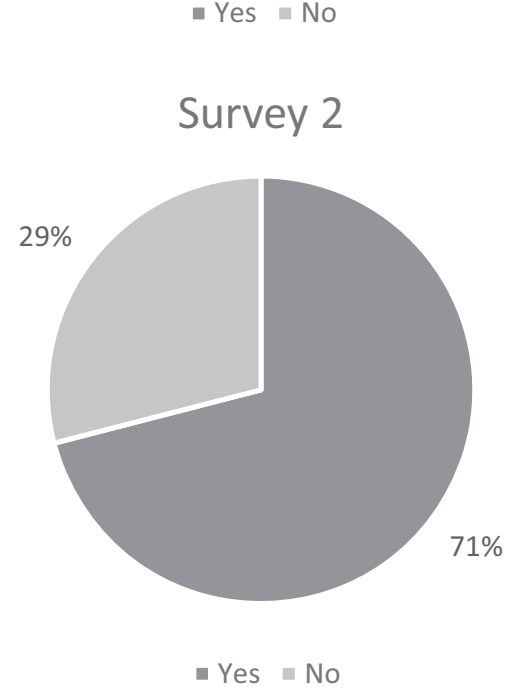

Fig. 2 Survey question: Do you wear scrubs when seeing both low (asymptomatic/no contacts) and high risk COVID19 patients in your Ophthalmology department?

Table 3 Survey question: What type of PPE do you wear while examining low risk, asymptomatic patients?

\begin{tabular}{|c|c|c|c|c|c|c|}
\hline & \multirow{2}{*}{\multicolumn{2}{|c|}{$\begin{array}{l}\text { Hospitals, } \\
n=29 \\
\text { Survey } 1\end{array}$}} & \multirow{2}{*}{\multicolumn{2}{|c|}{$\begin{array}{l}\text { Hospitals, } \\
n=32 \\
\text { Survey } 2\end{array}$}} & \multirow{2}{*}{\multicolumn{2}{|c|}{$\begin{array}{l}\text { Optome- } \\
\text { trists, } \\
n=21 \\
\text { Survey } 1\end{array}$}} \\
\hline & & & & & & \\
\hline & No. & $\%$ & No. & $\%$ & No. & $\%$ \\
\hline Apron & 10 & $34 \%$ & 21 & $66 \%$ & 3 & $14 \%$ \\
\hline Eye protection (total) & 8 & $28 \%$ & 20 & $63 \%$ & 1 & $3 \%$ \\
\hline Eye protection-visor & 1 & $3 \%$ & 7 & $22 \%$ & 0 & $0 \%$ \\
\hline Eye protection-goggles & 7 & $24 \%$ & 13 & $41 \%$ & 1 & $5 \%$ \\
\hline Face mask (total) & 27 & $93 \%$ & 31 & $97 \%$ & 14 & $48 \%$ \\
\hline $\begin{array}{l}\text { Face mask-fluid resistant surgical } \\
\text { mask (FRSM) }\end{array}$ & 26 & $90 \%$ & 29 & $91 \%$ & 10 & $48 \%$ \\
\hline $\begin{array}{l}\text { Face mask-FFP3 (filtering } \\
\text { face piece) }\end{array}$ & 0 & $0 \%$ & 2 & $6 \%$ & 4 & $19 \%$ \\
\hline Regular surgical mask & 1 & $3 \%$ & 0 & $0 \%$ & 0 & $0 \%$ \\
\hline Gown & 0 & $0 \%$ & 1 & $3 \%$ & 0 & $0 \%$ \\
\hline Gloves & 18 & $62 \%$ & 28 & $88 \%$ & 12 & $57 \%$ \\
\hline Slit lamp guard & 27 & $93 \%$ & 30 & $94 \%$ & 19 & $90 \%$ \\
\hline
\end{tabular}


Table 4 Survey 1 and Survey 2 responses for additional questions.

\begin{tabular}{|c|c|c|c|c|c|c|c|c|c|c|c|c|}
\hline \multirow{2}{*}{$\begin{array}{l}\text { Survey } 1 \\
\text { My hospital provided me with adequate information } \\
\text { regarding PPE }\end{array}$} & \multicolumn{2}{|c|}{$\begin{array}{l}\text { Strongly } \\
\text { agree }\end{array}$} & \multicolumn{2}{|c|}{ Agree } & \multicolumn{2}{|c|}{ Neutral } & \multicolumn{2}{|c|}{ Disagree } & \multicolumn{2}{|c|}{$\begin{array}{l}\text { Strongly } \\
\text { disagree }\end{array}$} & N/A & \multirow{2}{*}{$\begin{array}{l}\text { No response } \\
\text { given }\end{array}$} \\
\hline & 4 & $17 \%$ & 7 & $30 \%$ & 5 & $22 \%$ & 3 & $13 \%$ & 4 & $17 \%$ & $0 \quad 0 \%$ & \\
\hline $\begin{array}{l}\text { The management responsible for the provision of PPE } \\
\text { in my department listen to my view and take it into } \\
\text { account }\end{array}$ & 4 & $18 \%$ & 7 & $32 \%$ & 2 & $9 \%$ & 7 & $32 \%$ & 2 & $9 \%$ & $0 \quad 0 \%$ & 7 \\
\hline $\begin{array}{l}\text { I have experienced a shortage of PPE during an } \\
\text { emergency eye care session }\end{array}$ & 0 & $0 \%$ & 5 & $23 \%$ & 3 & $14 \%$ & 7 & $32 \%$ & 4 & $18 \%$ & $314 \%$ & 7 \\
\hline $\begin{array}{l}\text { I have experienced objection or threat of disciplinary } \\
\text { action to wearing PPE I have provided myself }\end{array}$ & 3 & $14 \%$ & 2 & $9 \%$ & 2 & $9 \%$ & 5 & $23 \%$ & 4 & $18 \%$ & $627 \%$ & 7 \\
\hline $\begin{array}{l}\text { The management responsible for the provision of PPE } \\
\text { in my department have changed its guidance to me in } \\
\text { the last } 2 \text { weeks }\end{array}$ & 8 & $36 \%$ & 11 & $50 \%$ & 2 & $9 \%$ & 0 & $0 \%$ & 1 & $5 \%$ & $0 \quad 0 \%$ & 0 \\
\hline \multicolumn{13}{|l|}{ Survey 2} \\
\hline $\begin{array}{l}\text { My hospital is providing me with adequate information } \\
\text { regarding PPE }\end{array}$ & 8 & $25 \%$ & 17 & $53 \%$ & 4 & $13 \%$ & 2 & $6 \%$ & 1 & $3 \%$ & $0 \quad 0 \%$ & 0 \\
\hline $\begin{array}{l}\text { The management responsible for the provision of PPE } \\
\text { in my department/ practice listens to my view and takes } \\
\text { it into account }\end{array}$ & 7 & $22 \%$ & 12 & $38 \%$ & 9 & $28 \%$ & 3 & $9 \%$ & 1 & $3 \%$ & $0 \quad 0 \%$ & 0 \\
\hline $\begin{array}{l}\text { In the last week I have experienced a shortage of PPE } \\
\text { during an emergency eye care session }\end{array}$ & 0 & $0 \%$ & 2 & $6 \%$ & 1 & $3 \%$ & 20 & $63 \%$ & 6 & $19 \%$ & $39 \%$ & 0 \\
\hline $\begin{array}{l}\text { In the last week I have experienced objection or threat } \\
\text { of disciplinary action to wearing PPE I have provided } \\
\text { myself }\end{array}$ & 0 & $0 \%$ & 2 & $6 \%$ & 0 & $0 \%$ & 12 & $38 \%$ & 11 & $34 \%$ & $722 \%$ & 0 \\
\hline $\begin{array}{l}\text { The management responsible for the provision of PPE } \\
\text { in my department/practice have changed its guidance to } \\
\text { me in the last week (since the last survey). }\end{array}$ & 8 & $25 \%$ & 16 & $50 \%$ & 3 & $9 \%$ & 4 & $13 \%$ & 0 & $0 \%$ & $13 \%$ & 0 \\
\hline
\end{tabular}

professionals wearing personally acquired PPE by $11 \%$ and $11 \%$ respectively, for the same time period. See Table 4.

\section{Optometrists}

Twenty-one optometrists replied to survey $1-76 \%$ of which are affiliated to MECS/MECS type services.

See Table 3 for their PPE use.

\section{Discussion}

Our findings demonstrate a positive and significant adaptation of PPE in response to change in guidance published by PHE, RCOphth and BEECS between 16/3/ 20 and $11 / 4 / 20$.

Initial responses for health care workers during the COVID19 pandemic from PHE meant Ophthalmology was not on Trust radars as a high-risk specialty leading to Ophthalmologists and AHP feeling vulnerable to exposure and objection to self provided protection.
Early response by the RCOphth and BEECS included advice to install substantial guards to slit lamps, thereby creating a physical barrier to the transfer of aerosol droplets during close ocular examination [2]. Ninetythree percent of hospital EEC professions initially surveyed had slit lamp guards; however, not all units were compliant. With the initial guidance, many were forced to use temporary DIY homemade guards while awaiting robust options.

Prior to the change in PPE advice on 9/4/20, $17 \%$ of individuals experienced objection or threat of disciplinary action if they were seen to wear their own personally acquired PPE items. This reduced to $6 \%$ in the second survey, which may reflect the change in PHE recommendations and provision of additional PPE by the Government to the employers. There was an increase from $47 \%$ to $78 \%$ in respondents that were satisfied with the information they were given about PPE and from 50\% to $60 \%$ in those that felt management listened to them about their views on PPE provision.

Importantly after the 9/4/20 update, there was an increase in satisfaction with information about PPE and more felt 
their hospital management took into account the clinicians' views and listened to them about their views on PPE provision.

A reduction in the number of responses to our followup survey from the primary care ophthalmic practitioners (MECS and non-MECS practices) might reflect that many had to close their doors due to the lack of PPE, which was not prioritized in this sector. Those currently operating are providing telephone consultations and face to face emergency consultations where PPE has been provided.

\section{Conclusion}

The COVID19 pandemic has rapidly taken over the normal activity of Ophthalmic departments creating unprecedented challenges. Following initial confusion and vulnerability expressed by EEC professionals to PPE guidance, most Trusts appear to have adapted and are doing similar things. The response has been swift and effective as a result of good team work and early advice from BEECS and the RCOphth. Learning from other affected countries has been paramount when planning and adjusting to this new challenging situation. On the whole, management teams are listening and hopefully in the very near future our Primary care optometry colleagues will be provided with similar levels of PPE for continued collaboration in the management of ocular emergencies during this COVID19 global pandemic.

\section{Summary}

\section{What was known before}

- Very little was known before as this is a novel infection. No health planning for this type of pandemic.

\section{What this study adds}

- A positive and significant adaptation of PPE in response to change in guidance. Most Trusts appear to have adapted and are doing similar things.

Acknowledgements We acknowledge BEECS committee members for this work.

\section{Compliance with ethical standards}

Conflict of interest The authors declare that they have no conflict of interest.

Publisher's note Springer Nature remains neutral with regard to jurisdictional claims in published maps and institutional affiliations.

\section{References}

1. WHO. www.WHO.int. Accessed April 2020.

2. Royal College of Ophthalmologists. www.rcophth.ac.uk. Accessed March 2020.

3. www.college-optometrists.org. Accessed April 2020.

4. Wu Z, McGoogan JM. Characteristics of and important lessons from the coronavirus disease 2019 (COVID-19) Outbreak in China: Summary of a Report of 72314 Cases From the Chinese Center for Disease Control and Prevention. JAMA 2020;323:1239-42.

5. Zhou Y, Zeng Y, Tong Y, Chen C. Ophthalmologic evidence against the interpersonal transmission of 2019 novel coronavirus through conjunctiva. medRixiv. 2020. https://www.medrxiv.org/ content/10.1101/2020.02.11.20021956v1.

6. Wu P, Duan F, Luo C, et al. Characteristics of ocular findings of patients with coronavirus disease 2019 (COVID-19) in Hubei Province, China. JAMA Ophthalmol. 2020. https://doi.org/10. 1001/jamaophthalmol.2020.1291.

7. Lu CW, Liu XF, Jia ZF. 2019-nCoV transmission through the ocular surface must not be ignored. Lancet. 2020. https://doi.org/ 10.1016/s0140-6736(20)30313-5.

8. Li JO, Lam DSC, Chen Y, et al. Novel Coronavirus Disease 2019 (COVID-19): the importance of recognising possible early ocular manifestation and using protective eyewear. $\mathrm{Br} \mathrm{J}$ Ophthalmol. 2020;104:297-8. 